\title{
PENERTIBAN DAN PENDAYAGUNAAN TANAH TERLANTAR DALAM RANGKA PENATAGUNAAN TANAH DI KOTA TARAKAN
}

\author{
Cariono \\ Pemerintah Kota Tarakan \\ Tarakan, Kalimantan Utara, Indonesia \\ cariono_trk@gmail.com
}

\section{Abstract}

The presence of land controlled and / or owned by either existing rights above the ground and based on the new land acquisition in some places there are still many in limbo. Seeing the reality of the field on the wastelands, he made government regulation and government last issued Government Regulation No. 11 Year 2010 on Land Reform and Control of Neglected. Based on this background, the problem is formulated, what basic criteria for establishing a right to the top of the ground as the object of regulating the wastelands, who preferred to get right to the land above the ground of the former wastelands, this research was normative approach legislation conceptual and legal materials. The results showed that the controlling authority is the authority wastelands legacy which the Government (President) delegate to the National Land Agency of the Republic of Indonesia. The mechanism through penertibannya stages: (1) an inventory of land rights or land tenure policies that indicated displaced (2) identification and study of land indicated displaced (3) warning against the rights holder (4) Determination of wastelands. Other Issues Regarding legal protection against former titleholders.

Keywords: effectiveness, enforcement, wastelands

\section{PENDAHULUAN}

Tanah merupakan salah satu unsur kehidupan yang penting bagi manusia. Keberadaannya mempengaruhi aktivitas manusia, baik sebagai individu dalam memenuhi kebutuhan pribadi dan keluarganya, maupun sebagai anggota masyarakat dan warga Negara. Ketergantungan manusia akan tanah menimbulkan hubungan yang bersifat fisik dan yuridis. Hubungan secara fisik berupa memanfaatan dan penggunaan di atas tanah. Sedangkan hubungan yang bersifat yuridis berupa hak atas tanah yang memberi wewenang bagi pemegangnya untuk berbuat hukum mengalikan, memberikan hak atau menjaminkan kepada pihak lain. Bagi bangsa Indonesia, selain sebagai karunia Tuhan Yang Maha Esa, hubungan antara tanah dan bangsa Indonesia adalah bersifat abadi. 
Menurut Budi Harsono ${ }^{1}$, tanah dalam Pengertian yuridis diingatkan dalam Pasal 4 ayat (1) UUPA yaitu bahwa atas dasar hak menguasai dari Negara sebagai yang dimaksud dalam Pasal 2 ditentukan adanya macam-macam hak atas permukaan bumi, yang disebut tanah, yang dapat diberikan kepada dan dipunyai oleh orang-orang, baik sendiri maupun bersama-sama dengan orang lain serta badan hukum. Dengan demikian tanah yang diberikan kepada dan dipunyai oleh orang, orang-orang atau badan hukum dengan hak yang disediakan oleh UUPA adalah untuk digunakan atau dimanfaatkan. Diberikan dan dipunyainya tanah dengan hak-hak tersebut meliputi juga bagian tubuh bumi yang berada dibawahnya dan air serta ruang yang ada diatasnya sekedar yang berhubungan langsung dengan tanahnya.

Untuk mewujudkan cita-cita yang diinginkan oleh Pasal 33 ayat (3) UUD 1945 tersebut, maka pada tanggal 24 september 1960 diterbitkan Undang-Undang Pokok Agraria (selanjutnya disebut UUPA) yaitu UU nomor 5 tahun 1960 tentang Peraturan Dasar Pokok-Pokok Agraria. Menjelaskan UUPA menyatakan bahwa:

"Hukum agraria yang baru itu harus memberikan kemungkinan akan tercapainya fungsi bumi, air, ruang angkasa sebagaimana dimaksudkan diatas dan harus sesuai pula dengan kepentingan rakyat Indonesia dan Negara serta memenuhi keperluannya menurut jaman dalam segala soal agraria baik dari itu hukum agraria maksimal harus menunjukkan penjelasan dari pada asas kerohanian dari Negara dan cita-cita bangsa. Yaitu Ketuhanan Yang Maha Esa, Perikemanusiaan, Kebangsaan, Kerakyatan dan Keadialan Sosial serta Kekuasaanya harus merupakan pelaksanaan daripada ketentuan Pasal 33 UUD dan GBHN yang tercantum dalam manipesta Politik Republik Indonesia 17 Agustus 1945 dan ditegsaskan didalam Pidato Presiden tanggal 17 Agustus 1960." 2

Salah satu kebutuhan pokok manusia di bidang pemenuhan tempat tinggal. Kegiatan pembangunan perumahan akan sejajar dengan pertambahan jumlah penduduk. Bertambahnya jumlah penduduk akan meningkatkan kebutuhan akan tempat tinggalnya. Hal ini merupakan konsekuensi logis dari bertambahnya jumlah penduduk. Maka bertambahlah pembangunan kota dengan berdirinya perumahanperumahan dan pemukiman, bahkan sampai daerah pinggiran kota.

Terjadinya penelantaran, tanah mendorong ditertibkannya instruksi menteri Dalam Negeri Nomor 2 Tahun 1982 Tentang Penertiban Tanah Di Daerah Perkotaan Dikuasai oleh Badan Hukum/Perorangan yang tidak dimanfaatkan/ditelantarkan, sebagai pelaksanaan Keputusan Menteri Dalam Negeri Nomor 268 Tahun 1982 tentang Pokok-Pokok Kebijaksanaan Penertiban/Pemanfaatan Tanah yang dicadangkan bagi dan/atau dikuasai oleh perusahaan-perusahaan secara eksplisit objek dari penertiban tanah terlantar adalah tanah-tanah yang dikuasai dengan Hak Guna Bangunan (HGB) dan Hak Pakai (HP).

1 Budi Harsono, Hukum Agraria Indonesia Sejarah Pembentukan Undang-Undang Pokok Agraria ini dan Pelaksanaanya Jilid 1 Hukum Tanah Nasional, Djambutan , Jakarta, 2003, h. 54

${ }^{2}$ Lihat UUPA A Penjelasan Umum 1, Tujuan Undang-Undang Pokok Agraria Alenia 3 
Dalam perjalanannya, peraturan tersebut tidak dapat diimplementasikan secara maksimal, sehingga mengalami berbagai perubahan, bahkan ditingkatkan pengaturannya dengan peraturan pemerintah (selanjutnya disebut PP) nomor 36 tahun 1998 tentang Penertiban Dan Pendayagunaan Tanah Terlantar akan tetapi usaha-usaha penertiban selama kurang lebih 3 (tiga) tahun itu, juga tidak membuahkan hasil yang signifikan.

Menyikapi kondisi tersebut, maka tahun 2001 majelis permusyawaratan rakyat membuat ketetapan Nomor IX/MPR/2001 tentang Pembaharuan Agraria dan Pengelolaan Sumber Daya Alam Pasal 2 TAP MPR tersebut menyebutkan, bahwa "Pembaharuan agraria mencangkup suatu proses yang berkesinambungan dengan penataan penguasaan, pemilikan, penggunaan dan pemanfaatan sumber daya agraria, dilaksanakan dalam ragka tercapainya kepastian dan perlindungan hukum, serta keadilan dan kemakmuran bagi seluruh rakyat Indonesia".

Berangkat dari pencanangan pembaharuan agraria ini, baru pada tahun 2010 dikeluarkan Peraturan Pemerintah (PP) Nomor 11 Tahun 2010 tentang Penertiban dan Pendayagunaan Tanah Terlantar menggantikan PP Nomor 36 Tahun 1998 suatu kurun waktu yang lama sejak TAP MPR itu ditertibkan.

Adapun pertimbangan diterbitkannya PP Nomor 11 Tahun 2010 tersebut adalah:

1. Bahwa berdasarkan Pasal 27, Pasal 34 dan Pasal 40 Undang-Undang Nomor 5 Tahun 1960 tentang Peraturan Dasar Pokok-Pokok Agraria, hak atas tanah hapus antara lain karena ditelantar.

2. Bahwa saat ini penelantaran tanah makin menimbulkan kesenjangan sosial, ekonomi, dan kesejahteraan rakyat serta menurunkan kualitas lingkungan, sehingga perlu pengaturan kembali penertiban dan pendayagunaan tanah terlantar.

3. PP Nomor 36 Tahun 1998 tidak dapat lagi dijadikan acuan penjelasan penertiban dan pendayagunaan tanah terlantar sehingga perlu dilakukan penggantian.

Pengertian tanah terlantar menurut PP Nomor 11 Tahun 2010, dapat ditentukan pada rumusan Pasal 2 yaitu:

1. Tanah yang telah berstatus hak, yaitu hak milik, hak guna bangunan, hak guna usaha, hak pakai dan hak pengelolaan yang tidak diusahakan, tidak dipergunakan, atau tidak dimanfaatkan sesuai dengan keadaannya atau sifatnya dan tujuan pemberian hak atau sifatnya dan tujuan pemberian hak atau dasar penguasaannya.

2. Tanah yang telah memperoleh dasar penguasaan (ijin, keputusan, surat) apabila tanahnya tidak dimohon hak tidak diusahakan, tidak dipergunakan atau tidak dimanfaatkan sesuai dengan persyaratan atau ketentuan yang ditetapkan.

\section{RUMUSAN MASALAH}

Berdasarkan latar belakang tersebut diatas maka dapat dirumuskan permasalahan yang hendak diteliti:

1. Apa dasar kriteria untuk menetapkan suatu hak atas tanah sebagai objek penertiban tanah terlantar. 
2. Siapa yang diutamakan untuk memperoleh hak atas tanah terhadap tanah Negara bakas tanah terlantar.

\section{METODE PENELITIAN}

\section{Tipe Penelitian Hukum Normatif}

Menurut Peter Mahmud Mazuki3, penelitian hukum dilakukan untuk menghasilkan argumentasi, teori atau konsep baru sebagai presepsi dalam menyelesaikan masalah yang dihadapi. Oleh karena itu penelitian hukum adalah suatu proses untuk menemukan aturan hukum, prinsip-prinsip hukum, maupun doktrim-doktim hukum.

\section{Pendekatan masalah}

Identifikasi terhadap isu hukum ditemukan pada objek penertiban dan pendayagunaan tanah terlantar dan perlindungan hukum kepada pemilik hak atas tanah. Untuk menguraikan permasalahan hukum, yaitu kriteria objek penertiban dan pendayagunaan tanah terlantar dan perlindungan terhadap pemilik hak atas tanah, maka digunakan pendekatan masalah yaitu pendekatan perundangundangan (statute approach) dan pendekatan konseptual (conceptual approach).

\section{Analisis Bahan Hukum}

Bahan-bahan hukum terkumpul akan disusun secara kualitatif yaitu data dianalisis dengan tidak menggunakan statistik atau matematika atau sejenisnya namun cukup dengan menguraikan secara deskriptif dari data yang diperoleh. Dalam penetapan metode analisis ini disesuaikan dengan katagori data dan keinginan peneliti. Dari pembahasan tersebut, akan ditarik kesimpulan secara dedukatif yaitu penarikan kesimpulan dari yang bersifat umum kepada khusus.

\section{PEMBAHASAN}

\section{Konsep Tanah Terlantar}

Menurut J.J.H. Bruggink, Her begrip is datgene dat in ons denken ontstaat als de betekems van her woord, gezien de verwijzing van dat woord noor een bepaald object of person. Hierboven is nog eens gezegd dat die betekenis afhangt van zowel de talige als de buiten-tahge contekst. ${ }^{4}$ Pengertian adalah apa yang timbul dalam pikiran kita sebagai arti dari perkataan, mengingat penunjukan perkataan itu pada obyek tertentu atau orang tertentu. Jadi bergantung pada baik konteks keabsahan maupun bukan keabsahan. b. Kriteria Tanah Terlantar

Kriteria tanah terlantar dapat ditemukan dengan cara mensisternatisasi unsure-unsur yang ada dalam tanah terlantar. Adapun unsur-unsur yang ada pada tanah tenlantar:

1. Adanya pemilik atau pemegang hak atas tanah (subyek).

2. Adanya tanah hak yang duahakan aiau tidak (obyek).

3. Adanya tanah yang tendentifikasi telah menjadi hutan kembali atau kesuburannya tidak terjaga.

4. Adanya jangka waktu tertentu dimana tanah menjadi tidak produktif. Page. 46

3 Peter Mahmud Marzuki, Penelitian Hukum, Kencana Prenada Media Grup, h.35

4 J.J.H.Bruggink,1993,Rechtsreflecties Grondbegrippen uit de rechtstheorie, Deventer, Kluwer, 
5. Adanya perbuatan yang sengaja tidak mengguaakan tanah.

6. Status tanah kembali kepada Negara.

Dengan mengetahui unsur-unsur esensial terjadinya tanah terlantar maka kriteria atau ukuran yang dapat dipakai untuk menetapkan sebidang tanah adalah terlantar dengan cara keinbali menjelaskan dengan melakukan penafsiranpenafsiran terhadap unsur yang ada, dengan fokus terhadap tujuan pemberian hak atas tanah. Sehingga apabila dan kondisi fisik tampak tanah tidak terawat atau tidak terpelihara itu berarti tidak sesuai dengan tujuan pemberian haknya. Dengan demikian kriteria tanah terlantar adalah:

1) Harus ada pemilik atau pemegang hak atas tanah (subyek).

2) Harus ada tanah hak (Hak Milik, Hak Guna Usaha, Hak Guna Bangunan,dan lainlain) yang tidak terpelihara dengan baik sehingga kualitas kesuburan tanahnya menurun.

3) Harus ada jangka waktu tertentu.

4) Harus ada perbuatan yang dengan sengaja tidak menggunakan Tanah sesuai dengan keadaan atau sifat dan tujuan haknya.

Berdasarkan konsep tanah terlantar yang diatur dalam Penjelasan Pasal 27 UUPA yang menyatakan: Tanah ditelantarkan kalau dengan sengaja tidak dipergunakan sesuai dengan keadaannya atau sifat dan tujuan dan pada haknya, maka kriteria tanah terlantar dalam UUPA kurang jelas atau masih kabur karena hanya ditentukan subyek hak/pemegang hak atas tanah obyek hak (Hak Milik, Hak Guna Usaha, Hak Guna Bangunan), dan ada perbuatan yang mengakibatkan tanah menjadi terlantar, sedangkan jangka waktunya tidak ditentukan.

Dalam Peraturan PemerintahNomor 36 Tahun 1998 kriteria tanah terlantar diatur dalam Bab III, yang dibagi menjadi tiga bagian:

Bagian Kesatu mengenai tanah Hak Milik Hak China Usaha, Hak Guna Bangunan dan Hak Pakai meliputi:

Pasal 3 yang menyatakan bahwa:

"Tanah Hak Milik, Hak Guna Usaha, Hak Guna Bangunan, dan Hak Pakai dapat dinyatakan sebagai tanah terlantar apabila tanah tensebut dengan sengaja tidak dipergunakan oleh pemegang haknya sesuai dengan keadaannya atau sifat dan tujuan haknya atau tidak dipelihara dengan baik." Pasal 4 yang menyatakan bahwa:

"Tanah Hak Milik, Hak Guna Bangunan atau Hak Pakai yang tidak dimaksudkan untuk dipecah menjadi beberapa bidang tanah dalam rangka penggunaannya tidak dipergunakan sesuai dengan keadaannya atau sifat dan tujuan haknya sebagaimana dimaksud dalam Pasal 3, apabila tanah tersebut tidak dipergunakan sesuai dengan peruntukannya menurut Rencana Tata Ruang Wilayah yang berlaku pada waktu permulaan penggunaan atau pembangunan fisik di atas tanah tersebut" Pasal 5 yang menyatakan bahwa:

(1) Tanah Hak Guna Usaha tidak dipergunakan sesuai dengan keadaannya atau sifat dan tujuan haknya sebagaimana dimaksud dalam Pasal 3, apabila tanah itu tidak diusahakan sesuai dengan kriteria pengusahaan tanah pertanian yang baik sesuai dengan ketentuan peraturan perundang-undangan yang berlaku. 
(2) Jika hanya sebagian dari bidang tanah Hak Guna Usaha sebagaimana dimaksud pada ayat (1) memenuhi kritena terlantar, maka hanya bagian tanah tersebut yang dapat dinyatakan terlantar.

Pasal 6 menyatakan bahwa:

(1) Tanah Hak Guna Bangunan atau Hak Pakai yang dimaksudkan untuk dipecah menjadi beberapa bidang tanah dalam rangka penggunaannya tidak dipergunakan sesuai dengan keadaannya atau sifat dan tujuan haknya sebagaimana dimaksud dalam Pasal 3, apabila tanah tersebut tidak dipecah dalam rangka pengembangannya sesuai dengan rencana kerja yang telah disetujui oleh instansi yang berwenang.

(2) Jika hanya sebagian dari bidang tanah Hak Guna Bangunan atau Hak Pakai sebagaimana dimaksud pada ayat (1) memenuhi kriteria terlantar, maka hanya bagian bidang tanah tersebut yang dapat dinyatakan tenlantar.

Bagian Kedua mengenai Tanah Hak Pengelolaan, meliputi:

Pasal 7 yang menyatakan behwa:

(1) Tanah Hak Pengelolaan dapat dinyatakan sebagai tanah terlantar, apabila kewenangan hak menguasai dari Negara atas tanah tersebut tidak dilaksanakan oleh pemegang Hak Pengelolaan sesuai tujuan pemberian pelimpahan kewenangan tersebut.

(2) Jika hanya sebagian dari bidang tanah Hak Pengelolaan sebagaimana dimaksud pada ayat (1) yang memenuhi kriteria terlantar, maka hanya bagian bidang tanah tersebut yang dapat dinyatakan terlantar.

Bagian Ketiga Tanah Yang Belum Dimohon Hak meliputi:

Pasal 8 yang menyatakan bahwa:

(1) Tanah yang sudah diperoleh penguasaannya, tetapi belum diperoleh hak atas tanah sesuai ketentuan peraturan perundang-undangan yang berlaku dapat dinyatakan sebagai tanah terlantar, apabila tanah tersebut oleh pihak yang telah memperoleh dasar penguasaan tidak dimohon haknya atau tidak dipelihara dengan baik.

(2) Jika hanya sebagian dari bidang tanah yang sudah diperoleh dan dikuasai sebagaimana dimaksud pada ayat (1) yang memenuhi kriteria tanah terlantar, maka hanya bagian bidang tanah tersebut yang dapat dinyatakan terlantar.

Dalam Peraturan Pemenintah Nomor 36 Tahun 1998 rumusan kriteria tanah terlantar masih kabur karena dalam peraturan tersebut tidak ditentukan jangka waktu tanah dinyatakan sebagai tanah terlantar. Dalam Peraturan Pemerintah tersebut ditentukan subyek/pemegang hak atas tanah, obyek hak (Hak Milik, Hak Guna Usaha, Hak Guna Bangunan Hak Pakai, Hak Pengelolaan), adanya perbuatan yang dapat mengakibatkan tanah menjadi terlantar.

Dalam Penjelasan Pasal 2 Peraturan Pemerintah Nomor 11 Tahun 2010 ditentukan tanah terlantar adalah tanah yang sudah diberikan hak oleh Negara berupa Hak Milik, Hak Guna usaha, Hak Guna Bangunan, Hak Pakai, dan Hak Pengelolaan, atau dasar penguasaan atas tanah yang tidak diusahakan, tidak dipergunakan, atau tidak dimanfaatkan sesuai dengan keadanya atau sifat dan tujuan pemberian hak atau dasar penguasaannya. Kemudian dalam Pasal 6 
Peraturan Pemerintah Nomor 11 Tahun 2010 dinyatakan bahwa identifikasi dan penelitian dilaksanakan: terhitung mulai 3 (tiga) tahun sejak diterbitkan Hak Milik Hak Guna Usaha, Hak Guna Bangunan, Hak Pakai atau sejak berakhirnya izin/keputusan/surat dasar penguasaan atas tanah dan pejabat yang berwenang.

\section{Kedudukan Tanah Terlantar}

Berdasarkan tata jenjang/hierarki hak-hak penguasaan atas tanah, hak menguasai dari negara itu merupakan perwujudan dan hak bangsa yang memberi wewenang kepada negara untuk mengatur penggunaan, pengusahaan dan peruntukan tanah, yang implementasinya dapat diberikan kepada perorangan/ individu atau Badan hukum berupa hak-hak atas tanah.

Hak-hak atas tanah membenikan wewenang kepada pemegang haknya untuk menggunakan tanahnya. Menurut Soedikno Mertokusumo, wewenang yang dipunyai oleh pemegang hak atas tanah terhadap tanahnya dibagi menjadi dua yaitu:

1. Wewenang Umum

Wewenang yang bersifat umum yaitu pemegang hak atas tanah mempunyai wewenang untuk menggunakan tanahnya, termasuk juga tubuh bumi, air dan ruang yang ada di atasnya sekadar diperlukan untuk kepentingan yang langsung berhubungan dengan penggunaan tanah itu dalam batas-batas menurut UUPA dan peraturan-peraturan hukum lain yang lebih tinggi (Pasal 4 ayat (2) UUPA).

2. Wewenang Khusus

Wewenang yang bersifat khusus yaitu pemegang hak atas tanah mempunyai wewenang untuk menggunakan tanahnya sesuai dengan macam hak atas tanahnya, misalnya wewenang pada tanah hak milik adalah dapat untuk kepentingan pertanian dan atau untuk mendirikan bangunan, wewenang pada tanah Hak Guna Bangunan adalah menggunakan tanah hanya untuk mendirikan dan mempunyai bangunan di atas tanah yang bukan miliknya, wewenang pada tanah Hak Guna usaha adalah menggunakan tanah hanya untuk kepentingan perusahaan di bidang pertanian, perikanan, peternakan, atau perkebunan. ${ }^{5}$

Disamping itu juga hak-hak atas tanah menentukan kewjiban yang harus dilaksanakan oleh pemegang hak atas tanah. Pasal 10 UUPA menyebutkan "Setiap orang dan badan hukum yang mempunyai sesuatu hak atas tanah pertanian pada asasnya diwajibkan mengerjakan atau mengusahakan sendiri secara aktif, dengan mencegah cara-cara pemerasan." Kemudian Pasal 15 menyebutkan "Memelihara tanah, termasuk menambah kesuburannya serta mencegah kerusakannya adalah kewajiban tiap-tiap orang, badan hukum atau instansi yang mempunyai hubungan hukum dengan tanah itu dengan mempehatikan pihak yang ekonomi lemah."

Pemegang hak atas tanah yang tidak melaksanakan kewajibannya sesuai dengan ketentuan Pasal 27 huruf a angka 3, Pasal 34 huruf e, Pasal 40 huruf e yang

5 Soedikno Mertokusumo, 1988, Hukum dan Politik Agraria, Karunika, Universitas Terbuka, Jakarta, h. 45. 
menentukan semua hak atas tanah tersebut akan hapus dan jatuh ke tangan negara apabila tanah tersebut ditelantarkan. Secara yuridis hak atas tanah menjadi hapus jika dibatalkan oleh pejabat yang berwenang sebagai sanksi terhadap tidak dipenuhinya kewajiban tersebut atau dilanggarnya sesuatu larangan oleh pemegang hak yang bersangkutan ${ }^{6}$. Lebih lanjut Boedi Harsono menyatakan keputusan pejabat tersebut bersifat konstitutif, dalam arti hak yang bersangkutan baru menjadi hapus dengan dikeluarkannya surat keputusan tersebut. Jika yang hapus hak-hak atas tanah primer, maka tanah yang bersangkutan menjadi tanah negara. ${ }^{7}$

Jadi dapat dikatakan bahwa kedudukan tanah terlantar akhirnya menjadi tanah negara atau kembali dalam hak penguasaan negara. Selanjutnya dapat diserahkan kepada subyek lain untuk segera diberdayakan kembali atau diusahakan kembali.

\section{Kewenangan Dalam Penertiban Tanah Terlantar}

Kewenangan berasal dari kata "wenang" yang artinya adalah hak dan kekuasaan untuk melakukan sesuatu. Wewenang adalah hak dan kekuasaan untuk bertindak sehingga kewenangan berarti kekuasaan untuk membuat/melakukan sesuatu ${ }^{8}$.

Philipus M. Hadjon menyatakan bahwa kewenangan itu diperoleh melalui tiga (3) cara yaitu :

1. Atribusi adalah wewenang untuk membuat keputusan yang langsung bersumber kepada Undang-undang dalam arti materiil. Dari pengertian tersebut nampaknya kewenangan yang didapat melalui cara atribusi oleh institusi pemerintah merupakan kewenangan asli.

2. Delegasi adalah penyerahan wewenang untuk membuat besluit oleh pejabat pemerintahan kepada pihak lain dalam artian adanya perpindahan dari pemberi delegasi (delegans) kepada penerima delegasi (delegatoris)

3. Mandat adalah suatu pelimpahan wewenang kepada bawahan dalam artian memberikan wewenang kepada bawahan untuk membuat keputusan atas nama pejabat yang memberi mandat dan tanggung jawab ada pada pemberi mandat, bukan merupakan tanggungjawab mandataris. ${ }^{9}$

\section{Organ Yang Berwenang Dalam Penertiban Tanah Terlantar}

Pasal 33 ayat (3) UUD 1945 menyatakan bahwa: "Bumi, air dan kekayaan alam yang terkandung di dalamnya dikuasai oleh Negara dan dipergunakan sebesar- besar kemakmuran rakyat." Dari kata "dikuasai oleh Negara" terlihat bahwa kewenangan dibidang pertanahan dilaksanakan oleh negara yang dalam

\footnotetext{
${ }^{6}$ Boedi Harsono, op.cit., h.339.

7 Ibid.

8 W.J.S. Poerwadaminta, 1982, Kamus Umum Bahasa Indonesia, Balai Pustaka, Jakarta, h.

${ }^{9}$ Philipus M. Hadjon I, loc.cit
} 
pelaksanaannya dilakukan oleh Pemerintah Pusat. Berdasarkan kewenangan yang bersumber pada konstitusi maka kemudian diterbitkan UU No. 5 Tahun 1960 yang mengatur masalah keagrariaan atau pertanahan sebagai bagian dari bumi.

Dalam Pasal 2 ayat (2) UUPA disebutkan bahwa negara sebagai personifikasi dari seluruh rakyat diberi wewenang untuk mengatur, yaitu membuat peraturan, menyelenggarakan dalam arti melaksanakan (execution), menggunakan (use), menyediakan (reservation), dan memelihara (maintenance), atas bumi, air dan ruang angkasa serta kekayaan alam yang terkandung didalamnya. Berdasarkan hak menguasai negara atas bumi, air dan kekayaan alam tersebut, maka kewenangan penguasaan dan pengurusan bidang pertanahan ada pada negara, di mana di bidang eksekutif

(pemerintahan) dijalankan oleh Presiden (Pemerintah) atau didelegasikan kepada Menteri. ${ }^{10}$

Kewenangan penertiban tanah terlantar merupakan kewenangan delegasi dari pemerintah (Presiden) kepada Badan Pertanahan Nasional Republik Indonesia. Ketentuan ini tersirat dalam Pasal 17 PP No.11 Tahun 2010 yang menyatakan bahwa: "Pelaksanaan penertiban tanah terlantar dan pendayagunaan tanah terlantar dilakukan oleh Kepala dan hasilnya dilaporkan secara berkala kepada Presiden." Dalam pelaksanaan penertiban tanah terlantar dibentuk sebuah panitia. Susunan keanggotaan panitia ini terdiri dari unsur Badan Pertanahan Nasional dan instansi terkait yang diatur oleh Kepala (Pasal 5 PP No.11 Tahun 2010). Melihat ketentuan tersebut terjadi kekaburan norma karena instansi terkait yang dimaksud tidak jelas. Sebagai tindak lanjut dari ketentuan Pasal 14 PP No.11 Tahun 2010 dikeluarkan Peraturan Kepala Badan Pertanahan Nasional No.4 Tahun 2010 tentang Tata Cara Penertiban Tanah Terlantar. Panitia yang dimaksud Pasal 5 PP No.11 Tahun 2010, dalam Peraturan

Kepala BPN No.4 Tahun 2010 adalah Panitia C yang terdiri dari Kanwil BPN, Pemerintah Daerah, dan instansi yang berkaitan dengan peruntukan tanahnya yang mempunyai wewenang untuk melakukan identifikasi dan penelitian tanah terindakasi terlantar. Berdasarkan Pasal 10 Peraturan Kepala BPN No. 4 Tahun 2010, Susunan keanggotaan panitia C terdiri atas :

a. Ketua : Kepala Kantor Wilayah

b. Sekretaris : Kepala Bidang Pengendalian Pertanahan dan

Pemberdayaan Masyarakat, merangkap anggota

c. Anggota :1. Sekretaris Daerah Kabupaten/Kota

2. Dinas/Instansi Provinsi yang berkaitan dengan peruntukan tanahnya

3. Dinas/instansi Kabupaten/Kota yang berkaitan dengan peruntukan tanahnya.

4. Kepala Kantor Pertanahan.

Dengan demikian maka organ yang berwenang dalam penertiban tanah terlantar adalah panitia C yang terdiri dari Kanwil BPN, Kantor Pertanahan,

10 Edy Ruchiyat, loc.cit 
Pemerintah Daerah dan instansi yang berkaitan dengan peruntukan tanah yang bersangkutan berwenang dalam melakukan identifikasi dan penelitian terhadap tanah yang terindikasi terlantar. Sedangkan penetapan tanah terlantar merupakan kewenangan Kepala Badan Pertanahan Nasional Republik Indonesia.

\section{Ruang Lingkup Wewenang Penertiban Tanah Terlantar.}

Berdasarkan pada PP No. 11 Tahun 2010 dan Peraturan Kepala BPN No.4 Tahun 2010 organ yang berwenang dalam penertiban tanah terlantar adalah Panitia C yang terdiri dari kanwil BPN, Kantor Pertanahan, Pemerintah Daerah dan instansi yang berkaitan dengan peruntukan tanah yang bersangkutan dan Kepala Badan Pertanahan Nasional Republik Indonesia. Adapun wewenang yang dimiliki adalah :

\section{Panitia $\mathrm{C}$}

Berdasarkan Pasal 7 PP No.11 Tahun 2010 dan Pasal 11 Peraturan Kepala BPN No. 4 Tahun 2010 Panitia C memiliki wewenang untuk melakukan: a. Kegiatan identifikasi dan penelitian yang meliputi :

1) Melakukan verifikasi data fisik dan data yuridis;

2) Mengecek buku tanah dan / atau warkah dan dokumen lainnya untuk mengetahui keberadaan pembebanan, termasuk data, rencana dan tahapan penggunaan dan pemanfaatan tanah pada saat pengajuan hak;

3) Meminta keterangan dari Pemegang Hak dan pihak lain yang terkait, dan Pemegang Hak dan pihak lain yang terkait tersebut harus memberi keterangan atau menyampaikan data yang diperlukan;

4) Melaksanakan pemeriksaan fisik;

5) Melaksanakan ploting letak penggunaan dan pemanfaatan tanah pada peta pertanahan;

6) Membuat analisis penyebab terjadinya tanah terlantar;

7) Menyusun laporan hasil identifikasi dan penelitian; 8) Melaksanakan sidang Panitia; dan 9) Membuat berita acara.

b. Menyampaikan laporan hasil identifikasi, penelitian dan Berita Acara kepada Kepala Kantor Wilayah.

2. Kepala Kantor Wilayah Badan Pertanahan Nasional berwenang :

a. Memberikan peringatan kepada Pemegang Hak yang telah menelantarkan tanahnya berdasarkan hasil identifikasi dan penelitian yang telah dilakukan oleh Panitia C. Berdasarkan Pasal 8 PP No.11 Tahun 2010 dan Pasal 14 Peraturan Kepala BPN No.4 Tahun 2010 dinyatakan :

1) Apabila berdasarkan hasil identifikasi dan penelitian sebagaimana dimaksud dalam Pasal 7 ayat (2) disimpulkan terdapat tanah terlantar, maka Kepala Kantor Wilayah memberitahukan dan sekaligus memberikan peringatan tertulis pertama kepada Pemegang Hak, agar dalam jangka waktu 1 (satu) bulan sejak tanggal diterbitkannya surat peringatan, menggunakan tanahnya sesuai keadaannya atau menurut sifat dan tujuan pemberian haknya atau sesuai izin / keputusan / surat sebagai dasar penguasaannya. 
2) Apabila Pemegang Hak tidak melaksanakan peringatan sebagaimana dimaksud pada ayat (1), Kepala Kantor Wilayah memberikan peringatan tertulis kedua dengan jangka waktu yang sama dengan peringatan pertama.

3) Apabila Pemegang Hak tidak melaksanakan peringatan sebagaimana dimaksud pada ayat (2), Kepala Kantor Wilayah memberikan peringatan ketiga dengan jangka waktu yang sama dengan peringatan kedua.

b. Mengusulkan kepada Kepala Badan Pertanahan Nasional Republik Indonesia untuk menetapkan tanah yang bersangkutan sebagai tanah terlantar. Ketentuan ini diatur dalam Pasal 8 ayat (6) yang menyatakan bahwa: Apabila Pemegang Hak tetap tidak melaksanakan peringatan sebagaimana dimaksud dalam ayat (3), Kepala Kantor Wilayah mengusulkan kepada Kepala untuk menetapkan tanah yang bersangkutan sebagai tanah terlantar.

3. Kepala Badan Pertanahan Nasional Republik Indonesia

Kepala Badan Pertanahan Nasional Republik Indonesia berwenang untuk membuat keputusan penetapan tanah terlantar terhadap tanah yang diusulkan oleh Kepala Kantor Wilayah BPN. Ketentuan ini diatur dalam Pasal 9 PP No.11 Tahun 2010 dan Pasal 19 Perraturan Kepala BPN No.4 Tahun 2010. Pasal 19 Peraturan Kepala BPN No. 4 Tahun 2010 menyatakan bahwa :

a. Kepala menetapkan Keputusan Penetapan Tanah Terlantar atas usulan Kepala

Kantor Wilayah;

b. Keputusan sebagaimana dimaksud pada ayat (1), memuat hapusnya hak atas tanah, pemutusan hubungan hukumnya, dan sekaligus menegaskan bahwa tanah dimaksud dikuasai langsung oleh Negara.

\section{Mekanisme Penertiban Tanah Terlantar}

Berdasarkan Pasal 4 ayat (1) UUPA, yang menyatakan bahwa "Atas dasar hak menguasai negara atas tanah sebagai yang dimaksud dalam Pasal 2 ditentukan adanya macam-macam hak atas permukaan bumi, yang disebut tanah, yang dapat diberikan kepada dan dipunyai oleh orang-orang, baik sendiri maupun bersamasama dengan orang-orang lain serta badan-badan hukum".

Beberapa ketentuan UUPA yang berkaitan dengan tanah terlantar dapat dikemukakan sebagai berikut:

1. Hak milik atas tanah hapus bila tanahnya jatuh kepada Negara karena ditelantarkan (Pasal 27 poin a. 3). Penjelasan Pasal 27 menyatakan: "Tanah ditelantarkan kalau dengan sengaja tidak dipergunakan sesuai dengan keadaannya atau sifat dan tujuan dari pada haknya".

2. Hak Guna Usaha hapus karena ditelantarkan ( Pasal 34 e ).

3. Hak Guna Bangunan hapus karena ditelantarkan ( Pasal 40 e ).

Pemberitahuan akan dilakukan suatu tindakan penertiban harus berisi antara ain : 
a) Gambaran tentang keadaan atau sikap yang bersifat illegal dari peraturan yang dilanggar disebutkan.

b) Pemberitahuan harus jelas, sehingga yang diberitahu itu mengerti apa yang harus dilakukan.

c) Tenggang waktu yang diberikan harus jelas dan tegas.

d) Pemberitahuaan itu harus mengandung suatu kepastian, bahwa akan benarbenar dilaksanakan, sebab kalau hanya kira-kira akan dilakukan penertiban, maka hal itu akan bertentangan dengan asas kepastian.

Berdasarkan PP No.11 Tahun 2010 tentang Penertiban dan Pendayagunaan Tanah Terlantar yang ditindaklanjuti dengan Peraturan Kepala Badan Pertanahan Nasional Nomor 4 Tahun 2010 tentang Tata Cara Penertiban Tanah Terlantar, penertiban tanah terlantar dilakukan dengan tahapan sebagai berikut :

a. Inventarisasi tanah hak atau dasar penguasaan atas tanah yang terindikasi terlantar;

b. Identifikasi dan penelitian tanah terindikasi terlantar;

c. Peringatan terhadap pemegang hak;

d. Penetapan tanah terlantar.

Dalam PP No 11 Tahun 2010 dan Peraturan Kepala BPN No.4 Tahun 2010 pasal 20 dinyatakan : Sebagai bahan pertimbangan dalam Penetapan tanah terlantar dengan memperhatikan luas tanah terlantar terhadap tanah hak/dasar penguasaan, dilakukan pengelompokan berdasarkan persentasenya sebagai berikut:

1. seluruh hamparan tanah hak/dasar penguasaan terlantar atau $100 \%$ diterlantarkan;

2. sebagian besar terlantar, dengan kisaran $>25 \%-<100 \%$ diterlantarkan, dan

3. sebagian kecil terlantar, dengan kisaran $\leq 25 \%$ diterlantarkan.

Apabila seluruh hamparan tanah yang ditelantarkan maka keputusan penetapan Tanah Terlantar diberlakukan terhadap seluruh hamparan hak atas tanah tersebut. Jika sebagian hamparan yang ditelantarkan maka keputusan penetapan tanah terlantar diberlakukan terhadap seluruh hak atas tanah tersebut, dan selanjutnya kepada bekas pemegang hak diberikan kembali sebagian tanah yang benar-benar diusahakan, dipergunakan, dan dimanfaatkan sesuai dengan keputusan pemberian haknya, dengan melalui prosedur permohonan hak atas tanah. Terhadap tanah yang ditelantarkan kurang dari atau sama dengan 25 (dua puluh lima ) persen maka keputusan penetapan tanah terlantar diberlakukan hanya terhadap tanah yang ditelantarkan dan pemegang hak dapat mengajukan permohonan revisi luas bidang tanah tersebut.

\section{PENUTUP}

\section{Kesimpulan}

Berdasarkan hasil penelitian dan pembahasan pada bab sebelumnya maka dapat disimpulakan:

a. Bagaimana dasar kriteria untuk menetapkan suatu hak atas tanah sebagai objek pemerintah tanah terlantar, secara teoritis memberikan masukan dan 
menjadi acuan. Dengan mengetahui unsur-unsur esensial terjadinya tanah terlantar maka kriteria atau ukuran yang dapat dipakai untuk menetapkan sebidang tanah adalah terlantar, dengan cara melakukan penafsiranpenafsiran terhadap unsur yang ada. Dengan demikian kriteria tanah terlantar adalah:

1) Harus ada pemilik atau pemegang hak atas tanah (subyek).

2) Harus ada tanah hak (Hak Milik, Hak Guna Usaha, Hak Guna Bangunan,dan lain-lain) yang tidak terpelihara dengan baik sehingga kualitas kesuburan tanahnya menurun.

3) Harus ada jangka waktu tertentu.

4) Harus ada perbuatan yang dengan sengaja tidak menggunakan Tanah sesuai dengan keadaan atau sifat dan tujuan haknya.

Dalam Penjelasan Pasal 2 Peraturan Pemerintah Nomor 11 Tahun 2010 ditentukan tanah terlantar adalah tanah yang sudah diberikan hak oleh Negara berupa Hak Milik, Hak Guna usaha, Hak Guna Bangunan, Hak Pakai, dan Hak Pengelolaan, atau dasar penguasaan atas tanah yang tidak diusahakan, tidak dipergunakan, atau tidak dimanfaatkan sesuai dengan keadanya atau sifat dan tujuan pemberian hak atau dasar penguasaannya. Kemudian dalam Pasal 6 Peraturan Pemerintah Nomor 11 Tahun 2010 dinyatakan bahwa identifikasi dan penelitian dilaksanakan: terhitung mulai 3 (tiga) tahun sejak diterbitkan Hak Milik Hak Guna Usaha, Hak Guna Bangunan, Hak Pakai atau sejak berakhirnya izin/keputusan/surat dasar penguasaan atas tanah dan pejabat yang berwenang.

b. Siapa yang diutamakan untuk memperoleh hak atas tanah terhadap tanah Negara bekas tanah terlantar. Dalam melakukan tindakan penertiban tanah terlantar Pemerintah harus memperbaiki asas-asas pemerintahan yang baik yaitu asas bertindak cermat dan asas keseimbangan, asas kecermatan berkaitan dengan tindakan dalam melakukan identifikasi dan penelitian tanah terlantar. Tanah-tanah yang telah ditetapkan sebagai tanah oleh terlantar akan menjadi tanah Negara dan dikuasai oleh Negara. Sebagai langkah selanjutnya tanah-tanah terlantar tersebut akan didayagunakan untuk kepentingan masyarakat, dan pihak mendapatkan prioritas adalah pemegang hak atas tanah bekas tanah terlantar. Berdasarkan Pasal 15 PP No 11 Tahun 2010, dinyatakan bahwa peruntukan penguasaan, pemilikan penggunaan dan pemanfaatan tanah Negara bekas tanah terlantar didayagunakan untuk kepentingan masyarakat program strategis Negara dan untuk cadangan Negara.

\section{Saran}

Atas dasar hasil penelitian dan uraian dalam pembahasan serta simpulan maka diberikan saran-saran sebagaimana berikut ini:

a. Untuk pemerintah hendaknya menyempurnakan atau memperbaiki PP No. 11 Tahun 2010 tentang penertiban dan pendayagunaan tanah terlantar, khususnya mengenai konsep/pengertian tanah terlantar criteria untuk di perjelas lagi dan menyederhanakan mekanisme pelaksanaan penertiban, mulai pekerjaan identifikasi oleh satuan tugas, memberikan rekomendasi hasil 
identifikasi pada tim penilai kabupaten/kota, kantor wilayah sampai kepada menteri yang akan membuat penetapan terhadap suatu bidang tanah adalah terlantar. Hal ini disarankan agar tidak terjadi perbedaan persepsi antara para petugas dilapangan.

b. Agar pihak yang menguasai dan mengelola tanah terlantar dapat memberikan perhatian lebih besar terhadap upaya penyelesaian konflik disebabkan konflik melibatkan kepentingan masyarakat umum agar tidak mengakibatkan kerusakan dan kerugian yang lebih besar lagi bagi para pihak.

\section{DAFTAR BACAAN}

Bruggink, J.J.H. alih bahasa B.Arief Sidharta, Refleksi Tentang Hukum. Citra Aditya Bakti. Bandung, 1999

Chomzah, Ali Achmad. Hukum Pertanahan Seri Hukum Pertanahan I Pemberian Hak Atas Tanah Negara Dan Seri II Sertifikat dan permasalahannya. Prestasi Pusaka. Jakarta, 2002

Diantha Pasek I Made. Metodologi Penelitian Hukum Normatif Dalam Justifikasi Teori

Hukum. Prenada Media Group Jakarta, 2016

Fauzan. Kaedah Penemuan Hukum Yurisprudensi. Nusa Media Bandung, 2011

Gautama, Sudargo. Tafsiran Undang-Undang Pokok Agrarian. Alumni. Bandung, 1981

Hadjon, Philipus M. Djumiati, Titiek Sri. Argumentasi Hukum. Gajah Mada University Press. Yogyakarta, 2009

Hadjon, Philipus M. Lotulung. Paulus Effendie. Marzuki. H.M. Laica. Djamiati. Titiek

Sri. I Gusti Ngurah. Hukum Administrasi dan Good Government. Universitas Trisakti. Jakarta, 2010

Handjon, Philipus, M. Perlindungan Hukum Bagi Rakyat Di Indonesia, Peradapan. Universitas Trisakti. Jakarta, 2007

Harsono, Boedi. Hukum Agrarian Indonesia Sejarah Pembentukan Undang-Undang Pokok Agrarian, Isi Dan Pelaksanaannya Jilid I Hukum Tanah Nasional. Djambatan. Jakarta, 2008

Kelsen, Hans. Teori Hukum Turni Dasar-Dasar Ilmu Hukum Normative. Diterjemahkan Dari Buku Hans Kelsen.Pure Theory Of Low. Berkely University Of California Press. Nusa Media. Bandung, 2011

Lubis, Solly. M. Serba-Serbi Politik Dan Hukum. Sofmedia. Jakarta, 2011

Mahendra, Oka. Menguak Masalah Hukum, Demokrasi Dan Pertanahan. Pustaka Sinar harapan. Jakarta, 1996

Marzuki. Peter Mahmud. Penelitian Hukum. Kencana Prenada Media Group. Jakarta, 2010

Mertokusumo. Soedikno. Hukum Dan Politik Agrarian. Universitas Terbuka. Kanurika. Jakarta, 1988

Mertokusumo. Soedikno. Mengenal Hukum Suatu Pengantar. Yogyakarta. Liberty, 2002

Poerwadarminta. Kamus Umum Bahasa Indonesia. Balai Pustaka. Jakarta, 1987

Santoso. Urip. Hukum Agrarian Dan Hak-Hak Atas Tanah. Kencana. Jakarta, 2010 
Sembiring. Julius. Tanah Negara. STPN Press, 2012

Sitorus, Oloan dan Sierra, H.M.Zaki. Hukum Agrarian Di Indonesia Konsep Dasar Dan Implementasi, Mitra Kebijakan Tanah Indonesia. Yogyakarta, 2006

Suhariningsih. 2009. Tanah Terlantar Asas Dan Pembaharuan Konsep Menuju Penertiban. Prestasi Pustaka. Jakarta

Supriadi. Hukum Agraria. Sinar Grafika. Jakarta, 2015

Taneko. Soleman B. Hukum Adat Suatu Pengantar Awal Dan Prediksi Masa Mendatang. Eresco. Bandung, 1987

Ter Hear, B. Asas-Asas Dan Tatanan Hukum Adat. Mandar Maju. Bandung, 2011

Wignjodipoero, Soerojo. Pengantar Dan Asas-Asas Hukum Adat. Toko Gunung Agung. Jakarta, 1995

Yusriyadi. Industrialisasi Dan Perubahan Fungsi Sosial Hak Milik Atas Tanah. Gentah Publishing. Yogyakarta, 2010

Zein, ramli. Hak Pengelolaan Dalam Sistem UUPA. Rineka Cipta. Jakarta,1995 Zaedan Ali.M. Menuju Perubahan Hukum Pidana. Sinar Grafika Jakarta, 2015 